\title{
Reduced amyloid-A-degrading activity in serum in amyloidosis associated with rheumatoid arthritis
}

\author{
OTTO WEGELIUS, ANNA-MAIJA TEPPO, C PETER J MAURY
}

\begin{abstract}
The ability to degrade amyloid $A$ fibrils was studied in the serum of 31 patients with amyloidosis associated with rheumatoid arthritis, 33 patients with rheumatoid arthritis without amyloidosis, and 47 healthy controls. Fibrillar amyloid $A$ protein and the radial diffusion method were used.

The mean degrading activity in serum was significantly lower in patients with rheumatoid arthritis complicated by amyloidosis $(58 \pm 19 \%$ SD of the activity in a pooled sample of sera from 100 healthy blood donors used as standard) than in patients with rheumatoid arthritis alone (78 $\pm 14 \% ; p<0.001)$ or controls $(99 \pm 19 \% ; p<0.001)$

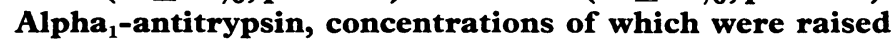
in both groups of patients, inhibited the degrading activity in serum even in low concentrations. A negative correlation between degrading activity and alpha $a_{1}$ antitrypsin concentrations was observed.

These findings suggest that reduced amyloid-Adegrading activity is due to inhibition rather than to deficiency of enzyme.
\end{abstract}

\section{Introduction}

Amyloidosis is characterised by extracellular deposition of protein fibrils with anti-parallel $\beta$-pleated sheet conformation. ${ }^{1}$ In amyloidosis secondary to chronic inflammation, including rheumatic diseases, ${ }^{2}$ these deposits contain amyloid A protein, which structurally has been regarded as a degradation product of serum amyloid A protein. ${ }^{45}$ Serum amyloid $\mathrm{A}$ is an acutephase protein, which occurs in high concentrations in amyloidosis and in rheumatic, inflammatory, and neoplastic diseases. ${ }^{6}$ ?

\footnotetext{
Fourth Department of Medicine, Helsinki University Central Hospital, 00170 Helsinki 17, Finland

OTTO WEGELIUS, MD, professor of internal medicine

ANNA-MAIJA TEPPO, MSC, clinical chemist

C PETER J MAURY, MD, assistant professor of internal medicine
}

We have examined the ability of serum to degrade amyloid A fibrils in patients with rheumatoid arthritis with or without amyloidosis and in healthy controls. We also measured serum amyloid A, C-reactive protein, and $\alpha_{1}$-antitrypsin concentrations.

\section{Patients and methods}

We studied two groups of patients with classic or definite rheumatoid arthritis (American Rheumatism Association criteria). One group comprised 13 men and 20 women (mean age 55.4 years), none of whom had signs of amyloidosis (confirmed by biopsy in a few cases); and the other comprised 12 men and 19 women (mean age 51.7 years), all of whom had biopsy-proved amyloidosis. Forty-seven healthy blood donors ( 31 men, 16 women; mean age 36.6 years) served as controls. Table I shows the duration of active rheumatoid arthritis, presence of rheumatoid factor in serum, serum creatinine concentrations, and degree of proteinuria in the two groups of patients.

The ability of serum to degrade fibrillar amyloid A protein was studied by radial diffusion in agarose gel containing amyloid $\mathrm{A}$ fibrils. ${ }^{8}$ a Briefly, amyloid A fibrils were extracted with distilled water ${ }^{10}$ from an amyloid human kidney and suspended in $1 \%$ agarose in phosphate-buffered saline, $\mathrm{pH} 7 \cdot 3$, at a concentration of $0.5 \mathrm{~g} / \mathrm{l}$. Wells $(4 \mathrm{~mm}$ diameter) were punched in the amyloid-agarose layer $(1.5 \mathrm{~mm}$ thick) and filled with $10 \mu \mathrm{l}$ serum samples. After overnight incubation at room temperature the diameters of the lysed areas around the wells were measured. A pooled sample of sera from 100 blood donors was used as standard and the splitting activity expressed as a percentage of the activity of the standard. The within-assay coefficient of variation of the method was $4 \cdot 8 \%$ and the between-assay variation $13.6 \% .^{9}$

The possible influence of renal insufficiency on the amyloid-splitting ability of serum was tested in 29 patients with impaired kidney function but with no signs of joint disease.

Serum amyloid A, C-reactive protein, and $\alpha_{1}$-antitrypsin concentrations were determined by radial immunodiffusion. Purified amyloid A protein was used as standard for serum amyloid A.

\section{Results}

Amyloid-A-degrading activity was significantly reduced in both groups of patients compared with the controls $(\mathrm{p}<0.001)$ (table II) and significantly lower in the patients with amyloidosis (mean $\mathbf{5 8 \%}$ of standard) than in those with rheumatoid arthritis alone (mean $78 \%$ of standard $)(p<0.001)$. In the separate group of 29 patients with 
impaired kidney function and no sign of joint disease renal insufficiency by itself did not affect the amyloid-splitting ability of serum. In that group mean values were: amyloid-A-degrading activity $101 \pm 16 \%$ SD of standard, $\alpha_{1}$-antitrypsin concentration $106+34 \%$ of standard, and serum creatinine concentration $571 \pm 306 \mu \mathrm{mol} / \mathrm{l} \quad(6.5 \pm$ $3.5 \mathrm{mg} / 100 \mathrm{ml}$ ). The amount of urinary protein in five patients with glomerular disease and heavy proteinuria also did not influence the amyloid-A-degrading activity of serum.

Mean serum amyloid A and C-reactive protein concentrations were significantly higher in the two groups of patients with rheumatoid
Mean $\alpha_{1}$-antitrypsin concentrations were higher in patients with rheumatoid arthritis alone $(\mathrm{p}<0.01)$ and complicated by amyloidosis $(p<0.001)$ than in the controls (table II). The difference between the two groups of patients, however, was not significant.

The effect of the activity of rheumatoid arthritis on the ability of serum to degrade amyloid A was studied in a woman with relapsing disease not complicated by amyloidosis (fig 1). During remission the raised serum concentrations of $C$-reactive protein, amyloid $A$, and $\alpha_{1}$-antitrypsin and decreased amyloid-A-degrading activity returned towards normal. A negative correlation was observed between the

TABLE I-Duration of rheumatoid arthritis, presence of rheumatoid factor in serum, serum creatinine concentration, and degree of proteinuria in patients with rheumatoid arthritis and patients with rheumatoid arthritis complicated by amyloidosis (mean values $\pm S D)$

\begin{tabular}{lccccc}
\hline \multicolumn{1}{c}{ Group } & $\begin{array}{c}\text { No of } \\
\text { patients }\end{array}$ & $\begin{array}{c}\text { Duration of } \\
\text { rheumatoid } \\
\text { arthritis } \\
\text { (years) }\end{array}$ & $\begin{array}{c}\text { No }(\%) \\
\text { seropositive for } \\
\text { rheumatoid factor } \\
\text { (Waaler-Rose test) }\end{array}$ & $\begin{array}{c}\text { Serum } \\
\text { creatinine } \\
(\mu \mathrm{mol} / 1)\end{array}$ & $\begin{array}{c}\text { Proteinuria } \\
(\mathrm{g} / \mathrm{l})\end{array}$ \\
\hline $\begin{array}{l}\text { Rheumatoid arthritis } \\
\text { Rheumatoid arthritis plus amyloidosis }\end{array}$ & 31 & $\begin{array}{c}8 \cdot 7 \pm 5 \cdot 9 \\
14 \cdot 9 \pm 7.5\end{array}$ & $\begin{array}{c}27(82) \\
12(39)\end{array}$ & $\begin{array}{c}\text { Normal } \\
242 \pm 193\end{array}$ & $3 \cdot 0 \pm 1 \cdot 9$ \\
\hline
\end{tabular}

Conversion: SI to traditional units-Creatinine: $1 \mu \mathrm{mol} / 1 \approx 0.01 \mathrm{mg} / 100 \mathrm{ml}$.

TABLE II-Mean ( $\pm S D$ ) amyloid-A-degrading activity and serum amyloid $A, C$-reactive protein, and $\alpha_{1}$-antitrypsin concentrations in patients with amyloidosis associated with rheumatoid arthritis, patients with rheumatoid arthritis alone, and controls

\begin{tabular}{|c|c|c|c|c|}
\hline & $\begin{array}{l}\text { (A) } \\
\text { Rheumatoid } \\
\text { arthritis plus } \\
\text { amyloidosis } \\
(\mathrm{n}=31)\end{array}$ & $\begin{array}{l}\text { (B) } \\
\text { Rheumatoid } \\
\text { arthritis } \\
(\mathrm{n}=33)\end{array}$ & $\begin{array}{c}(\mathrm{C}) \\
\text { Controls } \\
(\mathrm{n}=47)\end{array}$ & p Values \\
\hline Amyloid-A-degrading activity $(\%)^{*}$ & $58 \pm 19$ & $78 \pm 14$ & $99 \pm 19$ & $\left\{\begin{array}{l}(\mathrm{A}) v(\mathrm{~B}) \mathrm{p}<0.001 \\
(\mathrm{~A}) v(\mathrm{C}) \mathrm{p}<0.001 \\
(\mathrm{~B}) v(\mathrm{C}) \mathrm{p}<0.001\end{array}\right.$ \\
\hline Serum amyloid $A(\mathrm{mg} / \mathrm{l})$ & $51+59$ & $43 \pm 60$ & $<1$ & $\left\{\begin{array}{l}(\mathrm{A}) v(\mathrm{~B}) \mathrm{NS} \\
(\mathrm{A}) v(\mathrm{C}) \mathrm{p}<0.001 \\
(\mathrm{~B}) v(\mathrm{C}) \mathrm{p}<0.001\end{array}\right.$ \\
\hline C-reactive protein $(\mathrm{mg} / \mathrm{l})$ & $36 \pm 41$ & $17 \pm 22$ & $<5$ & $\left\{\begin{array}{l}(\mathrm{A}) v(\mathrm{~B}) \mathrm{p}<0.01 \\
(\mathrm{~A}) v(\mathrm{C}) \mathrm{p}<0.001 \\
(\mathrm{~B}) v(\mathrm{C}) \mathrm{p}<0.001\end{array}\right.$ \\
\hline$\alpha_{1}$-Antitrypsin (\%)* & $122 \pm 30$ & $125 \pm 61$ & $96 \pm 21$ & $\left\{\begin{array}{l}(\mathrm{A}) v(\mathrm{~B}) \mathrm{NS} \\
(\mathrm{A}) v(\mathrm{C}) \mathrm{p}<0.001 \\
(\mathrm{~B}) v(\mathrm{C}) \mathrm{p}<0.01\end{array}\right.$ \\
\hline
\end{tabular}

NS $=$ Not significant

Percentage of value in standard pool of sera from 100 healthy blood donors.

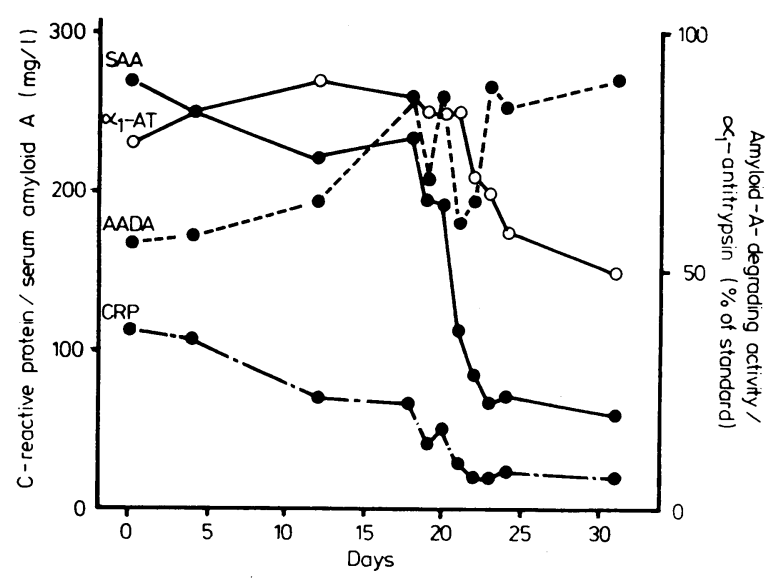

FIG 1-Amyloid-A-degrading activity (AADA) and serum amyloid $A(S A A), C$-reactive protein (CRP), and $\alpha_{1}$-antitrypsin $\left(\alpha_{1}-\mathrm{AT}\right)$ concentrations in women with rheumatoid arthritis in remission.

arthritis than in the controls (table II). Though the serum amyloid A concentration tended to be higher in the patients with amyloidosis than in those with rheumatoid arthritis alone, the difference was not statistically significant. C-reactive protein concentrations, however, were significantly higher in the patients with amyloidosis $(p<0.01$; table II). degrading activity and $\alpha_{1}$-antitrypsin values $(r=-0.68 ; \mathrm{p}<0.05)$.

Purified $\alpha_{1}$-antitrypsin inhibited degrading activity. The degree of inhibition bore a linear relation to the amount of $\alpha_{1}$-antitrypsin added (fig 2).

\section{Discussion}

We found that patients with rheumatoid arthritis complicated by amyloidosis had significantly lower amyloid-A-degrading activity in serum than healthy subjects or patients with rheumatoid arthritis but without signs of amyloidosis. This has important implications in the molecular pathogenesis of rheumatoid amyloidosis. Though in our study, as in some others, ${ }^{6}{ }^{711}$ serum amyloid A concentrations were increased in rheumatoid arthritis, the difference between patients with amyloidosis and those with rheumatoid arthritis alone was not significant. Moreover, an increase in serum amyloid A seems to be a general response of the organism to various stimuli. ${ }^{6} 711-14$ Additional factors are therefore concerned in the molecular mechanisms that lead to amyloidosis. One of these is reduced amyloid-A-degrading ability in the serum of patients with concomitant amyloidosis.

Patients with familial Mediterranean fever may also show deposits of amyloid $A$ protein and have reduced amyloiddegrading activity in serum. ${ }^{8}$

Purified $\alpha_{1}$-antitrypsin inhibits degradation of serum amyloid $\mathrm{A}^{15}$ and effectively inhibited the amyloid-A-degrading activity of 
normal serum. Moreover, the negative correlation between the $\alpha_{1}$-antitrypsin concentration and amyloid-A-degrading activity during changes in disease activity suggests that the $\alpha_{1}$-antitrypsin concentration regulates the degrading activity. The differences

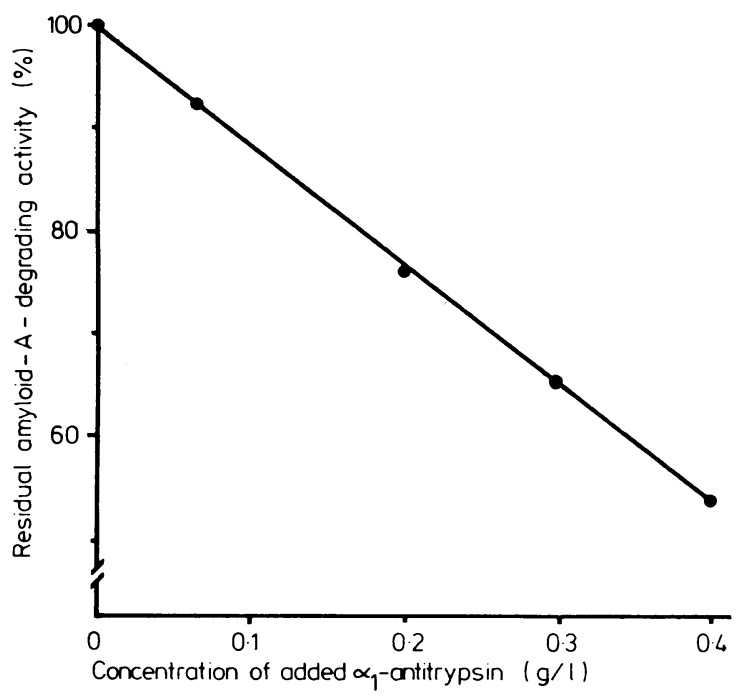

FIG 2-Inhibition of amyloid-A-degrading activity by $\alpha_{1-}$ antitrypsin.

in amyloid-A-degrading activity between patients with rheumatoid arthritis complicated by amyloidosis and those with rheumatoid arthritis alone cannot, however, be explained solely on the basis of the concentration of immunoreactive $\alpha_{1}$-antitrypsin.

We thank Dr Börje Skogen for the purified amyloid A protein. This study was supported by a grant from Liv och Hälsa, Finland.

\section{References}

1 Eanes ED, Glenner GG. X-ray diffraction studies of amyloid filaments. F Histochem Cytochem 1968;16:673-7.

2 Wegelius $O$, Wafin $F$, Falck $H$, Törnroth $T$. Follow-up study of amyloidosis secondary to rheumatoid arthritis. In: Glenner GG, Costa PP, Freitas F, eds. Amyloid and amyloidosis. Amsterdam: Excerpta Medica, 1980:183-90.

${ }^{3}$ Benditt EP, Eriksen N. Chemical classes of amyloid substance. Am $\mathcal{F}$ Pathol $1971 ; 65: 231-5$.

4 Husby G, Natvig JB. A serum component related to non-immunoglobulin amyloid AS, a possible precursor of the fibrils. $\mathcal{F}$ Clin Invest $1974 ; 53$ 1054-61.

${ }^{5}$ Lavie G, Zucker-Franklin D, Franklin EC. Degradation of serum amyloid A protein by surface-associated enzymes of human blood monocytes. f Exp Med 1978;148:1020-31.

6 Bensen MD, Cohen AS. Serum amyloid A protein in amyloidosis, rheumatic, and neoplastic diseases. Arthritis Rheum 1979 ;22:36-42.

7 Rosenthal CJ, Franklin EC. Variation with age and disease of an amyloid A protein-related serum component. $\mathcal{F}$ Clin Invest 1975;55:746-53.

${ }^{8}$ Kedar I, Ravid M, Sohar E. Amyloid degrading activity of human serum. In: Glenner GG, Costa PP, Freitas F, eds. Amyloid and amyloidosis. Amsterdam: Excerpta Medica, 1980:60-2.

- Teppo A-M, Maury CPJ, Wegelius O. Characteristics of the amyloidA-fibril-degrading activity in human serum. Scand $\mathcal{f}$ Immunol (in press).

${ }^{10}$ Pras M, Schubert M, Zucker-Franklin D, Rimon A, Franklin EC. The characterization of soluble amyloid prepared in water. $\mathcal{f}$ Clin Invest $1968 ; 47: 924-33$.

${ }^{11}$ Scheinberg MA, Benson MD. SAA amyloid protein levels in amyloidprone chronic inflammatory disorders. Lack of association with amyloid disease. $\mathcal{F}$ Rheumatol $1980 ; 7: 724-6$.

12 Gorevic PD, Rosenthal CJ, Franklin EC. Amyloid-related serum component (SAA). Studies in acute infections, medullary thyroid carcinoma and postsurgery. Behavior as an acute-phase reactant. Clin Immunol Immunopathol 1976;6:83-93.

${ }^{13}$ McAdam KPWJ, Elin RJ, Sipe JD, Wolff SM. Changes in human serum amyloid $\mathrm{A}$ and $\mathrm{C}$-reactive protein after etiocholanolone-induced inflammation. 7 Clin Invest $1978 ; 61: 390-4$

14 Selinger MJ, McAdam KPWJ, Kaplan MM, Sipe JD, Vogel SN, Rosenstreich DL. Monokine-induced synthesis of serum amyloid A protein by hepatocytes. Nature $1980 ; 285: 498-500$.

15 Silverman SL, Cathcart ES, Skinner M, Cohen AS, Burnett L. A pathogenetic role for polymorphonuclear leucocytes in the synthesis and degradation of SAA protein. In: Glenner GG, Costa PP, Freitas F, eds. Amyloid and amyloidosis. Amsterdam: Excerpta Medica, 1980:420-5.

(Accepted 26 November 1981)

\title{
Effect of venesection on calf blood flow in polycythaemia
}

\author{
D W MILLIGAN, J E TOOKE，J A DAVIES
}

\begin{abstract}
Calf blood flow at rest and during postocclusive reactive hyperaemia was measured using an electrocardiogramtriggered plethysmograph in 14 patients with polycythaemia (nine with primary disease and five with polycythaemia secondary to cyanotic heart disease) before and after a course of venesection. The mean packed cell volume was reduced from 0.57 to $0 \cdot 47$, and whole-blood viscosity fell by $50 \%$ at low shear rates. Venesection did not affect rest flow, but peak flow was increased by $18 \%$. The increase in peak flow failed to compensate for the reduced haemoglobin content of the blood, calculated haemoglobin delivery being reduced by $23 \%$ at rest and $10 \%$ during reactive hyperaemia.
\end{abstract}

\section{University Department of Medicine, The Martin Wing, The General} Infirmary, Leeds LS1 3EX

D W MILLIGAN, BSC, MRCP, tutor in medicine, honorary senior registrar J E TOOKE, MSC, MRCP, lecturer in medicine, honorary senior registrar J A DAVIES, MD, FRCP, senior lecturer in medicine, honorary consultant physician
These results indicate that while venesection improves blood viscosity, this does not necessarily lead to improved delivery of oxygen to the tissues.

\section{Introduction}

Polycythaemia, whether primary or secondary, is associated with both a rise in whole-blood viscosity and an increase in thrombotic events. ${ }^{1-3}$ Cerebral blood flow is reduced in patients with a raised packed cell volume and may return to normal after venesection. ${ }^{4-6}$ Peripheral blood flow may be reduced in polycythaemia, ${ }^{7}$ and this has been presumed to be directly related to hyperviscosity. ${ }^{7}$ Severe intermittent claudication is associated with increased whole-blood viscosity, ${ }^{9}$ and venesection may improve calf blood flow and haemoglobin delivery. ${ }^{10}$ Reduction of packed cell volume and hence viscosity by infusion of low-molecular-weight dextran also increased peripheral blood flow temporarily in patients with claudication. ${ }^{11}$

In this study we examined the influence of venesection on calf blood flow in patients with primary and secondary polycythaemia using a sensitive plethysmograph. 